Check for updates

Cite this: RSC Adv., 2017, 7, 35795

\title{
Performance of $\mathrm{ZnMn}_{2} \mathrm{O}_{4} / \mathrm{SiO}_{2}$ sorbent for high temperature $\mathrm{H}_{2} \mathrm{~S}$ removal from hot coal gas
}

\author{
Tzu-Hsing Ko, (D)*a Shumao Wang, (iD ${ }^{a}$ Feng-Hsiang Chang (D) ${ }^{\mathrm{b}}$ \\ and Chen-Yao Chu (D)
}

A spinel $\mathrm{ZnMn}_{2} \mathrm{O}_{4}$ sorbent supported on $\mathrm{SiO}_{2}$ was fabricated using a wetness impregnation method for high temperature desulfurization. The operating parameters including operating temperature, $\mathrm{ZnMn}_{2} \mathrm{O}_{4}$ content, space velocity, gas composition, and multiple desulfurization/regeneration cycles were evaluated to understand the optimal condition. The $\mathrm{ZnMn}_{2} \mathrm{O}_{4} / \mathrm{SiO}_{2}$ sorbent exhibits better desulfurization performance when operating temperature is controlled above $600{ }^{\circ} \mathrm{C}$ and the suitable space velocity is between 5000-15000 $\mathrm{h}^{-1}$. The relationship among $\mathrm{CO}, \mathrm{H}_{2}$, and $\mathrm{CO}_{2}$ on sorbent utilization could be explained via the water shift reaction. The sorbent utilization of the $\mathrm{ZnMn}_{2} \mathrm{O}_{4} / \mathrm{SiO}_{2}$ sorbent was retained at approximately $70 \%$ after ten desulfurization/regeneration cycles. Elemental analyses demonstrated that the formation of the spinel structure of $\mathrm{ZnMn}_{2} \mathrm{O}_{4} / \mathrm{SiO}_{2}$ improved the $\mathrm{Zn}$ stability and no $\mathrm{Zn}$ vaporization or loss were observed after ten desulfurization/regeneration cycles. $\mathrm{X}$ ray diffraction (XRD) and temperature programmed regeneration (TPR) were used to characterize the crystal phase and regeneration phenomena of the $\mathrm{ZnMn}_{2} \mathrm{O}_{4} / \mathrm{SiO}_{2}$ sorbent. XRD results demonstrated the presence of spinel structure of $\mathrm{ZnMn}_{2} \mathrm{O}_{4}$, and no $\mathrm{Zn}$ and $\mathrm{Mn}$ oxides were observed after multiple cycles, indicating that the $\mathrm{ZnMn}_{2} \mathrm{O}_{4} / \mathrm{SiO}_{2}$ sorbent is thermodynamically stable for high temperature desulfurization. Through the EDS and TPR analyses, the residual sulfur was found in the regenerated sorbent and this sulfur species is sulfate from incomplete regeneration. A regeneration temperature of $700{ }^{\circ} \mathrm{C}$ was the best choice to overcome the formation of metal sulfate.

Received 19th June 2017

Accepted 8th July 2017

DOI: $10.1039 / c 7 r a 06785 b$

rsc.li/rsc-advances the vaporization of $\mathrm{Zn}$, a series of metals were added with $\mathrm{Zn}$ to form alloy sorbents oxides for $\mathrm{H}_{2} \mathrm{~S}$ removal from hot coal gas. Huang et al. ${ }^{15}$ prepared $\mathrm{Zn}-\mathrm{Fe}-\mathrm{Mn} / \mathrm{MCM}-48$ sorbent for $\mathrm{H}_{2} \mathrm{~S}$ removal at $550{ }^{\circ} \mathrm{C}$ and the sorbent utilization of $66.1 \%$ was achieved. They also indicated that the significant decrease in sorbent utilization after regeneration. It was due to the migration of $\mathrm{Zn}$ onto the sorbent surface and $\mathrm{Zn}$ accumulated on the surface and vaporized to the exterior from the surface. Guo et al. ${ }^{16}$ evaluated the regeneration test of $\mathrm{Zn}-\mathrm{Mn}$ sorbent supported on $\gamma-\mathrm{Al}_{2} \mathrm{O}_{3}$ at $400{ }^{\circ} \mathrm{C}$ and $600{ }^{\circ} \mathrm{C}$. The results showed that the sulfur capacity decreased with regeneration cycles and over $50 \%$ sorbent utilization was loss after nine regeneration cycles for $400{ }^{\circ} \mathrm{C}$ and $600{ }^{\circ} \mathrm{C}$ due to the destruction of BET surface and pore structure. Furthermore, the previous study revealed that the addition of Mn significantly improves the vaporization of Zn, and it can be used for high-temperature desulfurization. In addition, some crucial operating parameters were obtained and established in the temperature range of $500-700{ }^{\circ} \mathrm{C} .{ }^{17}$

It is recognized that supported sorbents have high dispersion of activated species. The mesoporous silica have received much attention because of high surface, large pore volume and uniformly pore size distribution in comparison to $\mathrm{TiO}_{2}$ and $\gamma$ $\mathrm{Al}_{2} \mathrm{O}_{3}{ }^{18-21}$ To our knowledge the preparation and application of $\mathrm{Zn}-\mathrm{Mn}$ supported on $\mathrm{SiO}_{2}$ for high temperature desulfurization
${ }^{a}$ Anxi College of Tea Science, Fujian Agriculture and Forestry University, Fuzhou City, 350002, China.E-mail: hsingko@gmail.com

${ }^{b}$ Department of Tourism Affairs, Tzu Hui Institute of Technology, Nanjou Hsian, Pingtung County, Taiwan

${ }^{c}$ Yung-Hsing Financial Workshop Cooperation Company, Kaohsiung, Taiwan 
has not been investigated in-depth and incompletely understood. Therefore, in this study, the $\mathrm{ZnMn}_{2} \mathrm{O}_{4} / \mathrm{SiO}_{2}$ sorbent was systematically fabricated using a wetness impregnation method to obtain thermal-stable structure that is widely dispersed on $\mathrm{SiO}_{2}$. In addition to multiple desulfurization/regeneration cycles, X-ray diffraction (XRD), $\mathrm{N}_{2}$ adsorption with BrunauerEmmett-Teller (BET), temperature programmed regeneration (TPR), scanning electronic microscopy equipped with an energy dispersive spectroscopy (SEM/EDS), and elemental analysis were used to elucidate the surface and structure properties of fresh, reacted, and regenerated $\mathrm{ZnMn}_{2} \mathrm{O}_{4} / \mathrm{SiO}_{2}$ sorbent. The experimental results provide a new aspect for the development of new sorbents for high temperature desulfurization.

\section{Materials and methods}

\subsection{Preparation of $\mathrm{ZnMn}_{2} \mathrm{O}_{4}$ sorbent}

The $\mathrm{ZnMn}_{2} \mathrm{O}_{4}$ sorbents were prepared by using the wetness impregnation process with an aqueous solutions of $\mathrm{Mn}\left(\mathrm{NO}_{3}\right)_{2}$ $\cdot 4 \mathrm{H}_{2} \mathrm{O}$ and $\mathrm{Zn}\left(\mathrm{NO}_{3}\right)_{2} \cdot 4 \mathrm{H}_{2} \mathrm{O}$ as the precursors to form the structure of $\mathrm{ZnMn}_{2} \mathrm{O}_{4}$. Support materials used for the sorbent preparation were pure commercial products $\mathrm{SiO}_{2}, \mathrm{TiO}_{2}$ and $\gamma$ $\mathrm{Al}_{2} \mathrm{O}_{3}$ which were purchased from Sinopharm Chemical Reagent Company. All the chemical reagents used in this study were analytical grade.

First of all, pure $\mathrm{SiO}_{2}, \mathrm{TiO}_{2}$ and $\gamma-\mathrm{Al}_{2} \mathrm{O}_{3}$ were shattered and sieved to the desired size (50-100 mesh) and dried for $24 \mathrm{~h}$ before mixing with metal aqueous solution. For the preparation of $\mathrm{ZnMn}_{2} \mathrm{O}_{4} / \mathrm{SiO}_{2}$ sorbent, $12.4 \mathrm{~g}$ of $\mathrm{Mn}\left(\mathrm{NO}_{3}\right)_{2} \cdot 4 \mathrm{H}_{2} \mathrm{O}$ and $6.1 \mathrm{~g}$ of $\mathrm{Zn}\left(\mathrm{NO}_{3}\right)_{2} \cdot 4 \mathrm{H}_{2} \mathrm{O}$ were added in a $80 \mathrm{~mL}$ distilled water. The

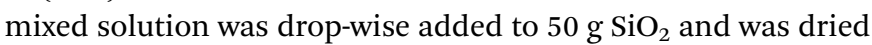
for $2 \mathrm{~h}$ at room temperature followed by drying for one day at $25{ }^{\circ} \mathrm{C}$ in an oven. For the preparation of $\mathrm{ZnMn}_{2} \mathrm{O}_{4} / \mathrm{TiO}_{2}$ sorbent, $11.3 \mathrm{~g}$ of $\mathrm{Mn}\left(\mathrm{NO}_{3}\right)_{2} \cdot 4 \mathrm{H}_{2} \mathrm{O}$ and $5.8 \mathrm{~g}$ of $\mathrm{Zn}\left(\mathrm{NO}_{3}\right)_{2} \cdot 4 \mathrm{H}_{2} \mathrm{O}$ were added in a $80 \mathrm{~mL}$ distilled water. The mixed solution was dropwise added to $50 \mathrm{~g} \mathrm{TiO}_{2}$ and was dried for $2 \mathrm{~h}$ at room temperature followed by drying for one day at $25{ }^{\circ} \mathrm{C}$ in an oven. For the preparation of $\mathrm{ZnMn}_{2} \mathrm{O}_{4} / \gamma-\mathrm{Al}_{2} \mathrm{O}_{3}$ sorbent, $11.4 \mathrm{~g}$ of $\mathrm{Mn}\left(\mathrm{NO}_{3}\right)_{2} \cdot 4 \mathrm{H}_{2} \mathrm{O}$ and $5.8 \mathrm{~g}$ of $\mathrm{Zn}\left(\mathrm{NO}_{3}\right)_{2} \cdot 4 \mathrm{H}_{2} \mathrm{O}$ were added in a 80 $\mathrm{mL}$ distilled water. The mixed solution was drop-wise added to $50 \mathrm{~g} \gamma-\mathrm{Al}_{2} \mathrm{O}_{3}$ and was dried for $2 \mathrm{~h}$ at room temperature followed by drying for one day at $25^{\circ} \mathrm{C}$ in an oven. Finally, all the samples were calcined at $700{ }^{\circ} \mathrm{C}$ for $2 \mathrm{~h}$ in air flow conditions.

\subsection{Desulfurization activity performance}

Simulative coal-derived gases consisted of $1 \% \mathrm{H}_{2} \mathrm{~S}, 25 \% \mathrm{CO}, 15 \%$ $\mathrm{H}_{2}$, and a balance of $\mathrm{N}_{2}$ from regulation cylinders, which are similar to the quenched exit gas of the popular Kellogg Rust Westinghousecoal gasifier. The gas flow rates were monitored through mass flow controllers. All mass flow controllers were monitored accurately by an infrared soap bubble meter and the concentration of all species were calculated at the condition of standard temperature and pressure. Prior to entering the reactor, the gases were conducted in a mixing pipe to confirm that the mixture gas exhibited turbulent flow. The reactor consisted of a quartz tube, $1.6 \mathrm{~cm}$ i.d., $2.0 \mathrm{~cm}$ o.d., and $150 \mathrm{~cm}$ length, located inside an electric furnace. Quartz fibres were placed in the reactor to support the samples. Two K-type thermocouples were exactly inserted into the reactor near the top and bottom of the samples to measure and control the inlet and outlet temperatures. Prior to the experiment, pure nitrogen gas (purity 99.99\%) was fed into the reactor for $30 \mathrm{~min}$ at $500{ }^{\circ} \mathrm{C}$ to remove adsorbed water and impure materials coated on the surface of the samples. In addition, blank breakthrough experiments were also conducted under the same conditions and it was verified that no reaction occurred anywhere between $\mathrm{H}_{2} \mathrm{~S}$ and the lines/reactor. The inlet and outlet concentration of $\mathrm{H}_{2} \mathrm{~S}$ were analysed by an on-line gas chromatograph (HP, GC-5890) equipped with a flame photometry detector (FPD) and fitted with a GS-Q capillary column. A six-port sampling with a $0.5 \mathrm{~mL}$ sampling loop was used to sample the inlet and outlet $\mathrm{H}_{2} \mathrm{~S}$ concentrations. The desulfurization experiment was terminated when the outlet $\mathrm{H}_{2} \mathrm{~S}$ concentration from the reactor approached the inlet $\mathrm{H}_{2} \mathrm{~S}$ concentration. After each desulfurization run, the reactor was purged with $\mathrm{He}$ gas for $15 \mathrm{~min}$, and regeneration began at $650{ }^{\circ} \mathrm{C}$ with $5 \% \mathrm{O}_{2}$. The regeneration experiment was terminated when the $\mathrm{SO}_{2}$ concentration in the effluent gas was lower than $10 \mathrm{ppm}$.

\section{3 $\mathrm{ZnMn}_{2} \mathrm{O}_{4}$ sorbent characterization}

Crystalline structures of the $\mathrm{ZnMn}_{2} \mathrm{O}_{4}$ sorbent before and after desulfurization/regeneration cycles were determined by X-ray powder diffraction (RIGAKU Model D/MAX III-V) with $\mathrm{CuK} \alpha$ radiation. The applied current and voltage were $30 \mathrm{~mA}$ and $40 \mathrm{kV}$, respectively. The diffraction patterns were recorded in the angle range $2 \theta=10-80^{\circ}$ at a scan rate of $3^{\circ} \mathrm{min}^{-1}$. The surface area was measured with a Micromeritics ASAP 2010 instrument using adsorption of nitrogen at $77 \mathrm{~K}$. Prior to adsorption measurements, the samples were degassed under vacuum conditions $(5 \mu \mathrm{m} \mathrm{Hg})$ at $100{ }^{\circ} \mathrm{C}$ for $2 \mathrm{~h}$. The surface area was calculated by the BET equation. The $\mathrm{ZnMn}_{2} \mathrm{O}_{4}$ sorbents were digested with aqueous aqua regia in a microwave oven. After digestion, filtration, and dilution processes, the extracted solution was analyzed by inductively coupled plasma atomic emission spectrometry (ICP/AES, JY38P model, JOBIN YVON) for determining the $\mathrm{Zn}$ and $\mathrm{Mn}$ contents.

\subsection{Temperature programmed regeneration (TPR) performance}

Temperature programmed regeneration (TPR) was performed by a thermogravimetric analysis equipped with differential thermal analysis (TGA/DTA, Perkin Elmer Pyris Diamond model). TPR experiments were conducted in a mixture of $5 \% \mathrm{O}_{2}$ and He. A quantity of $25 \mathrm{mg}$ of the reacted $\mathrm{ZnMn}_{2} \mathrm{O}_{4}$ sorbent was heated from room temperature to $900{ }^{\circ} \mathrm{C}$ at a heating rate of $10{ }^{\circ} \mathrm{C} \mathrm{min}^{-1}$. The sample was placed on a quartz-made reactor with a PID control electronic furnace. The gaseous sulfur compounds from the outlet in the TPR were measured and recorded with a gas chromatography (Shimadzu, GC-14B) equipped with a flame photometry detector. 


\subsection{Scanning electronic microscopy (SEM)/energy dispersive spectroscopy (EDS)}

Surface distribution of elements in red soils was obtained by using an EDS technique which employs a Phillip XL-40FEG scanning electron microscope. All the test samples were mounted on the $\mathrm{Cu}$ holder and were coated with platinum prior to EDS analysis.

\subsection{X-ray absorption spectroscopy (XAS)}

Mn K-edge spectra were undertaken on the wiggler beam-line at the National Synchrotron Radiation Research Center (NSRRC) of Taiwan. The electron storage ring operated at the energy of $1.3 \mathrm{GeV}$ and the beam current varied (current of 80-200 mA). A Si (111) double-crystal monochromator (DCM) was used for providing highly monochromatized photo beams with energies 1-9 keV.

\subsection{Solid-state nuclear magnetic resonance (SSNMR)}

The solid-state ${ }^{29} \mathrm{Si}$ MAS (magic angle spinning) NMR spectra of samples were recorded under 9.4 tesla with operating frequency of $104.2 \mathrm{MHz}$ on a Bruker Avance DSX400 spectrometer. Zirconia rotors were spun in air at $5 \mathrm{kHz}$. The deconvolution results and regression fitting of ${ }^{29} \mathrm{Si}$ MAS NMR were performed with Gaussian model using Origin 6.0 version software.

\subsection{Elemental analysis (EA)}

Elementar vario EL III Heraeus CHNOS Rapid F002, equipped with a flash combustion furnace and thermal conductivity detector (TCD) was used for determination of sulfur content after the desulfurization experimental processes.

\section{Results and discussion}

\subsection{Effect of supports}

To facilitate the expression of removal efficiency for $\mathrm{ZnMn}_{2} \mathrm{O}_{4}$, the sorbent utilization is used in this study and is defined as the ratio of the experimental breakthrough time and theoretical breakthrough time. The experimental breakthrough time is defined as the time from the beginning of the desulfurization to the point outlet $\mathrm{H}_{2} \mathrm{~S}$ concentration reached $50 \mathrm{ppm}$. The theoretical breakthrough time is defined as the time that $\mathrm{ZnMn}_{2} \mathrm{O}_{4}$ is completely reacted with $\mathrm{H}_{2} \mathrm{~S}$. The theoretical breakthrough time can be accurately determined based on the contents of $\mathrm{ZnMn}_{2} \mathrm{O}_{4}$ and the mass flow rate of $\mathrm{H}_{2} \mathrm{~S}$ and the stoichiometric reaction is represented as follows:

$$
\mathrm{ZnMn}_{2} \mathrm{O}_{4}+3 \mathrm{H}_{2} \mathrm{~S}+\mathrm{H}_{2} \rightarrow \mathrm{ZnS}+2 \mathrm{MnS}+4 \mathrm{H}_{2} \mathrm{O}
$$

To explore the effect of supports on the high temperature desulfurization, $10 \mathrm{wt} \% \mathrm{ZnMn}_{2} \mathrm{O}_{4}$ loading on various supports including $\mathrm{SiO}_{2}, \mathrm{TiO}_{2}$ and $\gamma-\mathrm{Al}_{2} \mathrm{O}_{3}$ were used and the result was shown in Fig. 1. Prior to the experiments performing, the blank, $\mathrm{SiO}_{2}, \mathrm{TiO}_{2}$ and $\gamma-\mathrm{Al}_{2} \mathrm{O}_{3}$ supports were preliminarily tested for their influence on the removal of $\mathrm{H}_{2} \mathrm{~S}$ and results indicated that no other reactions were observed between $\mathrm{H}_{2} \mathrm{~S}$ and supports. The influence of removal efficiency for supports can therefore

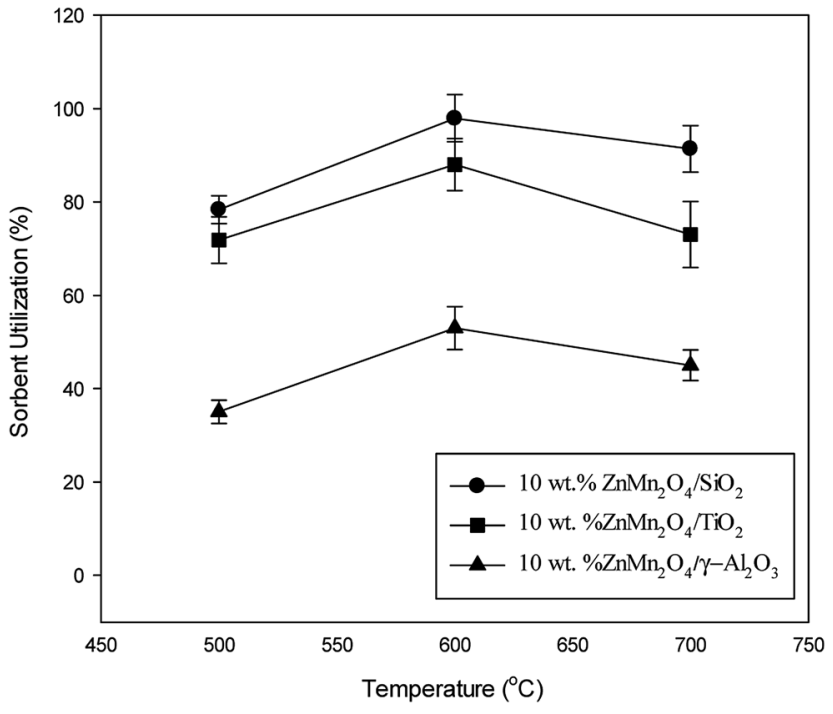

Fig. 1 Sorbent utilization as a function of temperature for $\mathrm{ZnMn}_{2} \mathrm{O}_{4}$ on different supports.

be neglected in this study. As shown in Fig. 1, the $\mathrm{SiO}_{2}$ is found to have the best sorbent utilization whereas $\gamma-\mathrm{Al}_{2} \mathrm{O}_{3}$ appeared to have the worst sorbent utilization. The optimal temperature for all samples was observed at $600{ }^{\circ} \mathrm{C}$. The sorbent utilization slightly decreased when temperature was controlled at $700{ }^{\circ} \mathrm{C}$. Surprisingly, the $\gamma-\mathrm{Al}_{2} \mathrm{O}_{3}$ support appeared to have low sorbent utilization. The $\gamma-\mathrm{Al}_{2} \mathrm{O}_{3}$ has the largest BET surface area among test supports. A reasonable reason for low sorbent utilization probably associated with the formation of the metal aluminium oxide, $\mathrm{MeAl}_{2} \mathrm{O}_{4}{ }^{22,23}$ Although $\mathrm{TiO}_{2}$ has a moderate sorbent utilization, its thermal stability is a key factor to govern the overall efficiency because of transformation of anatase to rutile/ brookite. Temperature exceeded $650{ }^{\circ} \mathrm{C}$ is a formation temperature for anatase into rutile form and results in a loss of surface area. ${ }^{24,25} \mathrm{SiO}_{2}$ is a thermal stability material and has been widely used as a support in catalytic field. In this study, $\mathrm{SiO}_{2}$ has the best sorbent utilization and only a slight decrease in sorbent utilization when temperature is controlled at $700{ }^{\circ} \mathrm{C}$. Therefore, $\mathrm{SiO}_{2}$ was chosen as a key role for the rest of the experiments.

\subsection{Effect of operating temperature}

Fig. 2 shows the effect of operating temperature on $\mathrm{ZnMn}_{2} \mathrm{O}_{4} /$ $\mathrm{SiO}_{2}$ utilization under the experimental condition of $T=400-$ $750{ }^{\circ} \mathrm{C}$. Experimental results indicate that sorbent utilization increases with operating temperature. The sorbent utilization maintains a stable state when the operating temperature was controlled over $600{ }^{\circ} \mathrm{C}$. No deactivation phenomenon is observed even the operating temperature exceed $750{ }^{\circ} \mathrm{C}$, implying that the addition of $\mathrm{Mn}$ improves the vaporization of $\mathrm{Zn}$ at high temperature. To understand the contents of $\mathrm{Zn}$ and $\mathrm{Mn}$, the fresh and used samples were analyzed with ICP to determine the contents of $\mathrm{Zn}$ and Mn. Table 1 shows the contents of $\mathrm{Zn}$ and $\mathrm{Mn}$ together with recoveries. Note that the recoveries of $\mathrm{Zn}$ for all samples are fairly good and no vaporization is found even at $750{ }^{\circ} \mathrm{C}$. This study is motivated to 


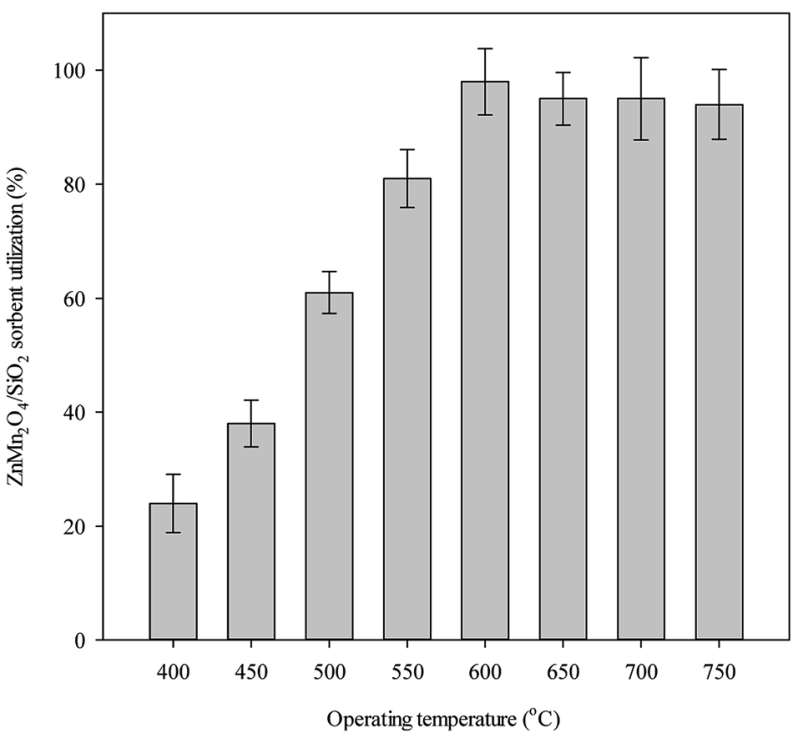

Fig. 2 Effect of operating temperature on $\mathrm{ZnMn}_{2} \mathrm{O}_{4} / \mathrm{SiO}_{2}$ sorbent utilization.

evaluate the effectiveness of applying $\mathrm{Mn}$ as a promoter to improve the shortcoming of $\mathrm{Zn}$-based sorbent for high temperature desulfurization. Indeed, $\mathrm{ZnMn}_{2} \mathrm{O}_{4} / \mathrm{SiO}_{2}$ sorbent shows good performance for $\mathrm{H}_{2} \mathrm{~S}$ removal at high temperature. Although it is well known that high temperature enhances the desulfurization efficiency, the equilibrium concentration of $\mathrm{H}_{2} \mathrm{~S}$ is a function of metal oxides and the inlet $\mathrm{H}_{2} \mathrm{O}$ content. For example, the equilibrium concentration of $\mathrm{H}_{2} \mathrm{~S}$ for the reaction of $\mathrm{MnO}_{2}$ and $\mathrm{H}_{2} \mathrm{~S}$ is $2.5 \mathrm{ppm}$ and $216 \mathrm{ppm}$ at $400{ }^{\circ} \mathrm{C}$ and $750{ }^{\circ} \mathrm{C}$ (gas composition involved $\mathrm{CO}: 42.5 \%, \mathrm{H}_{2}: 32.175 \%, \mathrm{H}_{2} \mathrm{O}$ : $\left.12.5 \%, \mathrm{CO}_{2}: 12.5 \%, \mathrm{H}_{2} \mathrm{~S}: 0.325 \%\right)$. When the operating temperature is controlled at $970{ }^{\circ} \mathrm{C}$ with the identical condition, the equilibrium concentration of $\mathrm{H}_{2} \mathrm{~S}$ is $100 \mathrm{ppm} .{ }^{26}$ Recent studies have revealed that desulfurization system components become prohibitively expensive as the operating temperature increases and the optimum desulfurization temperature is controlled between $350-600{ }^{\circ} \mathrm{C} .{ }^{27,28}$ Over such a range of temperatures, the efficiency of the process and its technical viability reduce the overall cost of the process.

\subsection{Effect of $\mathrm{ZnMn}_{2} \mathrm{O}_{4}$ content}

To investigate the effect of $\mathrm{ZnMn}_{2} \mathrm{O}_{4}$ content on the removal of $\mathrm{H}_{2} \mathrm{~S}$, various $\mathrm{ZnMn}_{2} \mathrm{O}_{4}$ contents ranging from 5.1-39.2 wt\% were carried out in order to understand the optimal preparation content. Fig. 3 exhibits the sorbent utilization as a function of the $\mathrm{ZnMn}_{2} \mathrm{O}_{4}$ content. More than $95 \%$ sorbent utilization was obviously achieved when the $\mathrm{ZnMn}_{2} \mathrm{O}_{4}$ content was controlled less than $14.8 \mathrm{wt} \%$. The sorbent utilization decreased with $\mathrm{ZnMn}_{2} \mathrm{O}_{4}$ content and only $60 \%$ sorbent utilization is observed for $39.2 \mathrm{wt} \%$ content. This implies that the higher sorbent utilization ranging from $5-15 \mathrm{wt} \%$ is attributed to a good dispersion of $\mathrm{ZnMn}_{2} \mathrm{O}_{4}$ on the $\mathrm{SiO}_{2}$ support. On the other hand, the higher content of $\mathrm{ZnMn}_{2} \mathrm{O}_{4}$ enhances the overall removal reaction from the kinetic consideration. The product, metal
Table 1 Contents of $\mathrm{Zn}$ and $\mathrm{Mn}$ together with the recovery for various sorbent states $^{a}$

\begin{tabular}{|c|c|c|}
\hline Sorbent state & $\begin{array}{l}\text { Contents of } \mathrm{Zn}, \mathrm{Mn} \\
\left(\mathrm{g} \mathrm{kg}_{\text {sorbent }}{ }^{-1}\right) \text { and } \\
\text { sulfur }(\%)\end{array}$ & $\begin{array}{l}\text { Recovery } \\
(\%)\end{array}$ \\
\hline Fresh sorbent & $\begin{array}{l}\mathrm{Zn}: 26.8 \\
\mathrm{Mn}: 46.3\end{array}$ & $\begin{array}{l}\mathrm{Zn}: 98.5 \\
\mathrm{Mn}: 100.4\end{array}$ \\
\hline Reacted sorbent at $600{ }^{\circ} \mathrm{C}$ & $\begin{array}{l}\mathrm{Zn}: 27.3 \\
\text { Mn: } 46.1 \\
\text { S: } 1.97\end{array}$ & $\begin{array}{l}\mathrm{Zn}: 100.4 \\
\mathrm{Mn}: 101.3\end{array}$ \\
\hline Reacted sorbent at $700{ }^{\circ} \mathrm{C}$ & $\begin{array}{l}\text { Zn: } 26.8 \\
\text { Mn: } 44.7 \\
\text { S: } 1.91\end{array}$ & $\begin{array}{l}\text { Zn: } 98.6 \\
\text { Mn: } 97.0\end{array}$ \\
\hline Reacted sorbent at $750^{\circ} \mathrm{C}$ & $\begin{array}{l}\text { Zn: } 27.2 \\
\text { Mn: } 46.8 \\
\text { S: } 1.89\end{array}$ & $\begin{array}{l}\text { Zn: } 100 \\
\text { Mn: } 101.6\end{array}$ \\
\hline Regenerated sorbent & $\begin{array}{l}\text { Zn: } 27.1 \\
\text { Mn: } 46.7 \\
\text { S: } 0.17\end{array}$ & $\begin{array}{l}\text { Zn: } 99.6 \\
\text { Mn: } 101.3\end{array}$ \\
\hline $\begin{array}{l}\text { Regenerated sorbent } \\
\text { after } 3 \text { cycles } \\
\text { Regenerated sorbent } \\
\text { after } 5 \text { cycles } \\
\text { Regenerated sorbent } \\
\text { after } 10 \text { cycles }\end{array}$ & $\begin{array}{l}\text { Zn: } 27.3 \\
\text { Mn: } 45.7 \\
\text { Zn: } 27.7 \\
\text { Mn: } 46.5 \\
\text { Zn: } 27.5 \\
\text { Mn: } 45.8 \\
\text { S: } 0.17\end{array}$ & $\begin{array}{l}\mathrm{Zn}: 100.4 \\
\text { Mn: } 99.1 \\
\text { Zn: } 101.8 \\
\text { Mn: } 100.9 \\
\text { Zn: } 101.1 \\
\text { Mn: } 99.3\end{array}$ \\
\hline
\end{tabular}

sulfides are dense materials, which increase the mass transfer resistance and further repress $\mathrm{H}_{2} \mathrm{~S}$ diffusion into the sorbent core. The sorbent utilizations for $10.2 \mathrm{wt} \%$ and $14.8 \mathrm{wt} \%$ are close to $100 \%$, however, the breakthrough curve of $14.8 \mathrm{wt} \%$ sorbent exhibits a more smooth feature than that of $10.2 \mathrm{wt} \%$ sorbent. This is due to the fact that diffusion resistance of $\mathrm{H}_{2} \mathrm{~S}$ through thick sulfide layer increases and reduces the reaction rate of internal oxide. Therefore, $10.2 \mathrm{wt} \% \mathrm{ZnMn}_{2} \mathrm{O}_{4} / \mathrm{SiO}_{2}$ sorbent is considered to be more available for a series of desulfurization reactions.

\subsection{Effect of space velocity}

The effect of space velocity on $\mathrm{ZnMn}_{2} \mathrm{O}_{4} / \mathrm{SiO}_{2}$ utilization is shown in Fig. 4. The operating temperature is controlled at $600{ }^{\circ} \mathrm{C}$ and the inlet concentration of gases is fixed at $1 \% \mathrm{H}_{2} \mathrm{~S}$, $25 \% \mathrm{CO}, 15 \% \mathrm{H}_{2}$, and a balance of $\mathrm{N}_{2}$. Results indicate that sorbent utilization reaches and maintains at the maximum value of $98 \%$ with the space velocity varying from 5000-15 000 $\mathrm{h}^{-1}$. The sorbent utilization is gradually decreased when the space velocity is increased to $20000 \mathrm{~h}^{-1}$. With the space velocity of $35000 \mathrm{~h}^{-1}$, the sorbent utilization is further reduced to $60 \%$, which is about $60 \%$ of the maximum value. Reduction of sorbent utilization at high space velocity might result from the limitation of diffusion. No significant change in the sorbent utilization within the ranges of 5000-15000 $\mathrm{h}^{-1}$, suggesting that the external mass transfer resistance can be ignored at this range. Space velocity can be further defined by the phase of the 


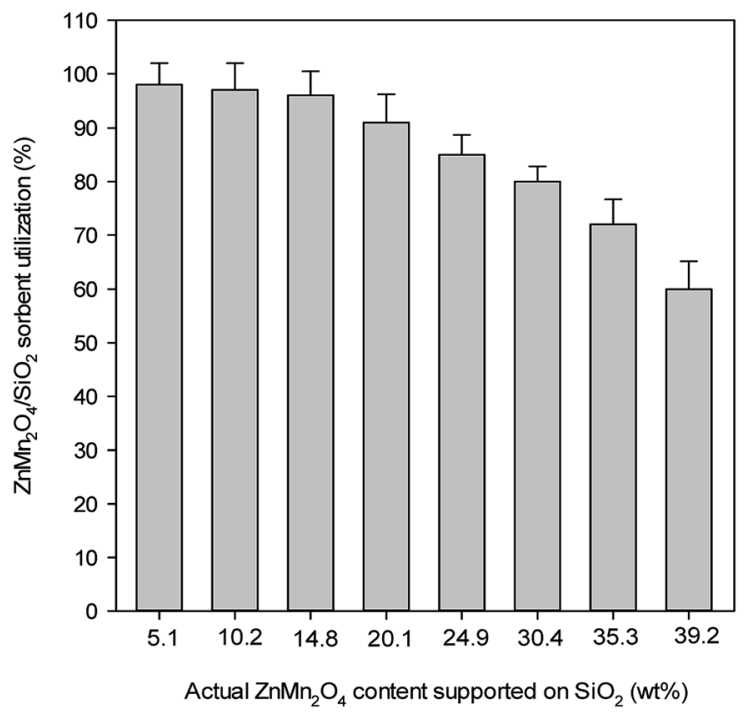

Fig. 3 Effect of $\mathrm{ZnMn}_{2} \mathrm{O}_{4}$ contents on the on $\mathrm{ZnMn}_{2} \mathrm{O}_{4} / \mathrm{SiO}_{2}$ sorbent utilization.

reactants at given conditions. Special values for this measurement exist for liquids and gases, and for systems that use solid catalysts. The effect of external mass transfer should be considered for the kinetic experiment when the space velocity is controlled more than $20000 \mathrm{~h}^{-1}$. The design of space velocity depends on the scale of gas composition and the size of desulfurization reactor.

\subsection{Effect of gas composition}

In addition to $\mathrm{H}_{2} \mathrm{~S}$, other gases such as $\mathrm{CO}, \mathrm{H}_{2}$ and $\mathrm{CO}_{2}$ are the main gaseous components that generated from syngas and their effects should be evaluated to understand the real condition. Fig. 5 shows the effect of different gas composition on sorbent utilization. Results indicate that the sorbent utilization

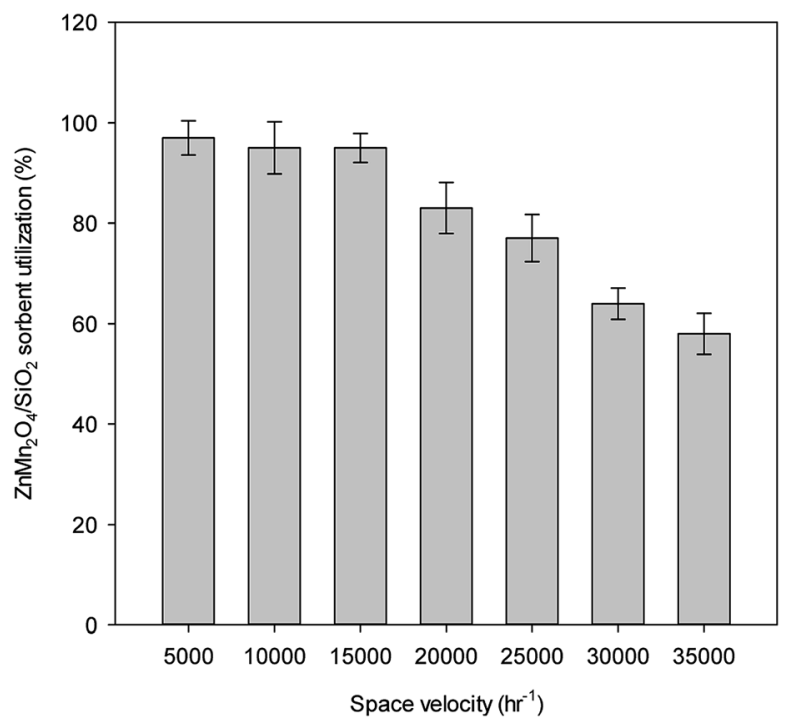

Fig. 4 Effect of space velocity on $\mathrm{ZnMn}_{2} \mathrm{O}_{4} / \mathrm{SiO}_{2}$ sorbent utilization. can be significantly increased when $\mathrm{CO}_{2}, \mathrm{H}_{2}$ and $\mathrm{CO}$ are introduced to the gas stream individually. In the presence of $\mathrm{CO}_{2}, \mathrm{H}_{2}$ and CO, the sorbent utilization increases from 47 to 61,95 , and $98 \%$. This may be explained by the water-shift reaction.

$$
\mathrm{CO}+\mathrm{H}_{2} \mathrm{O} \Leftrightarrow \mathrm{H}_{2}+\mathrm{CO}_{2}
$$

The water-gas shift reaction favors the right-hand side of the equation according to Le Chatelier's rule when $\mathrm{CO}$ concentration is increased. This also means that $\mathrm{H}_{2} \mathrm{O}$ is consumed in the water-gas shift reaction. Lower $\mathrm{H}_{2} \mathrm{O}$ content will favor reactions (2), which is in favor of the adsorption of $\mathrm{H}_{2} \mathrm{~S}$. Therefore, increasing the concentration of $\mathrm{CO}$ will enhance the adsorption reaction. On the other hand, increasing the concentration of $\mathrm{H}_{2}$ will favor the reaction toward left-hand side of the equation for the water-gas shift reaction results in formation of $\mathrm{H}_{2} \mathrm{O}$. Similarly, the adsorption progress is inhibited due to excess $\mathrm{H}_{2} \mathrm{O}$ formation from the water-gas shift reaction.

\subsection{Multiple cycles test for $\mathrm{ZnMn}_{2} \mathrm{O}_{4} / \mathrm{SiO}_{2}$ sorbent}

The experimental results of the ten successive desulfurization/ regeneration cycles are shown in Fig. 6. Nearly $100 \%$ of $\mathrm{ZnMn}_{2} \mathrm{O}_{4}$ sorbent utilization was achieved in the first cycle, indicating that all of the $\mathrm{ZnMn}_{2} \mathrm{O}_{4}$ sorbent reacted with $\mathrm{H}_{2} \mathrm{~S}$. The amount of $\mathrm{ZnMn}_{2} \mathrm{O}_{4} / \mathrm{SiO}_{2}$ sorbent utilization decreased gradually with an increase in the number of desulfurization/ regeneration cycles, and approached a stable state. The $\mathrm{ZnMn}_{2} \mathrm{O}_{4} / \mathrm{SiO}_{2}$ sorbent utilizations for 2, 3, 4, 5 and 10 cycles were $85 \%, 78 \%, 70 \%, 68 \%$ and $68.5 \%$, respectively. The $\mathrm{ZnMn}_{2} \mathrm{O}_{4} / \mathrm{SiO}_{2}$ sorbent utilization did not decrease further after multiple desulfurization/regeneration cycles. The reduction of approximately $30 \%$ of utilization was lost during the desulfurization/regeneration cycles. The reasons to cause the deactivation of sorbent probably attributed to (i) the vast loss of

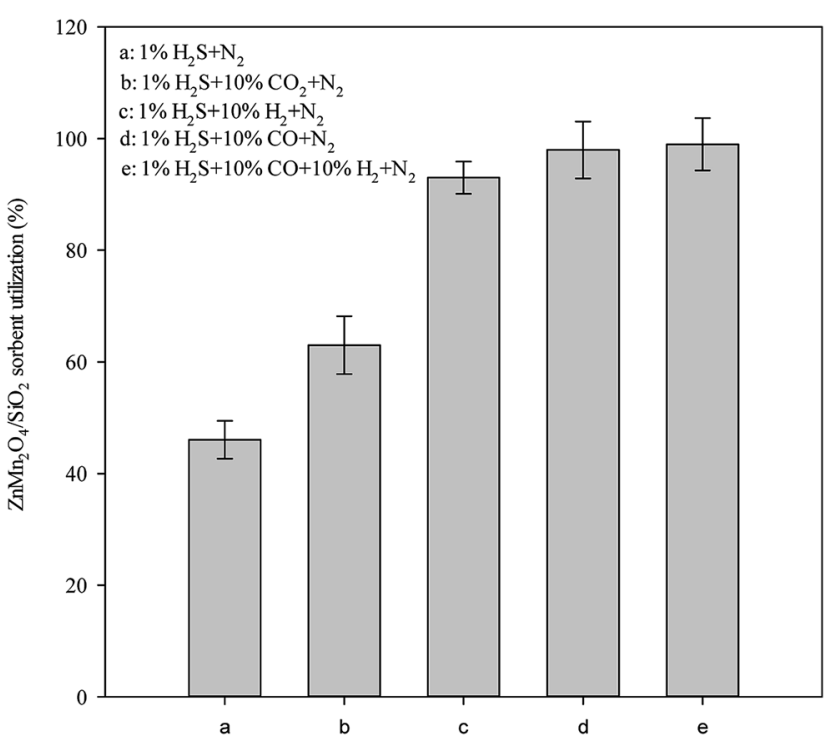

Fig. 5 Effect of gas composition on $\mathrm{ZnMn}_{2} \mathrm{O}_{4} / \mathrm{SiO}_{2}$ sorbent utilization. 
BET surface area, (ii) activated species loss, (iii) uncompleted regeneration. Regeneration is an intense exothermic reaction and the surface and bulk structures of the $\mathrm{ZnMn}_{2} \mathrm{O}_{4} / \mathrm{SiO}_{2}$ sorbent likely underwent a major change because of the exothermic condition. The $\mathrm{N}_{2}$ adsorption isotherm and pore size distribution for fresh, reacted and regenerated sorbents is shown in Fig. 7. It can be found that all the samples possessed the typical characteristic of type II isotherm according to the IUPAC classification. It indicated that all the sorbents exhibited a uniform ordered macro-pore structure. Furthermore, after desulfurization and regeneration processes the isotherm features have similar with the fresh sorbent, which means that the pore structures did not change too much before and after desulfurization and regeneration. BET surface areas were $86 \mathrm{~m}^{2}$ $\mathrm{g}^{-1}, 80 \mathrm{~m}^{2} \mathrm{~g}^{-1}$ and $76 \mathrm{~m}^{2} \mathrm{~g}^{-1}$ for fresh, reacted, and regenerated sorbents. On the other hand, the sorbent after ten desulfurization/regeneration cycles retained $70 \mathrm{~m}^{2} \mathrm{~g}^{-1}$ of BET surface area. As shown in Fig. 7, the fresh sorbent exhibited the smaller pore diameter ranging $10-20 \mathrm{~nm}$, while it ranged from 15-30 $\mathrm{nm}$ for the reacted sorbent. The probable reason was that few mesopores maybe collapsed during the high temperature desulfurization or resulted from the formation of metal sulfides because of larger radius of metal sulfides. After regeneration process, a broad feature of pore size distribution is obviously observed. The main pore diameter is in $20-80 \mathrm{~nm}$, which indicated that the regeneration reaction is the major reason to change pore size distribution and is attributed to the exothermic reaction from regeneration. Although BET surface area was found to decrease after reaction and regeneration, it may be one of the reasons to cause sorbents' degeneration because approximately $18 \%$ BET surface area was lost after ten successive desulfurization/regeneration cycles. As mentioned, the primary problem of a $\mathrm{Zn}$-based sorbent is the vaporization

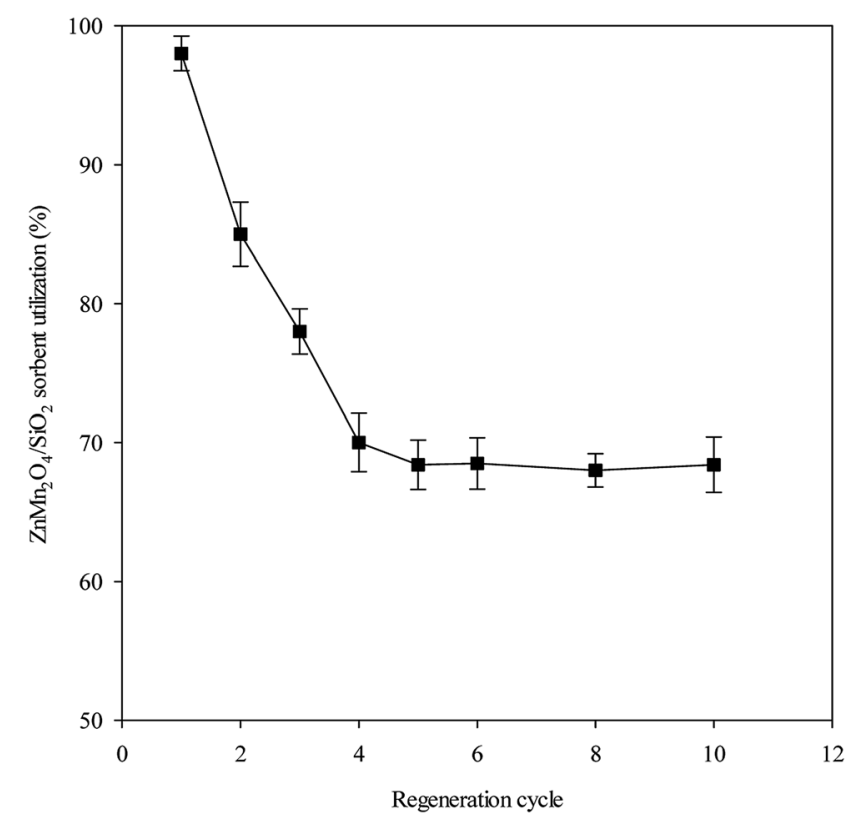

Fig. $6 \mathrm{ZnMn}_{2} \mathrm{O}_{4} / \mathrm{SiO}_{2}$ sorbent utilization as a function of multiple desulfurization/regeneration cycles.

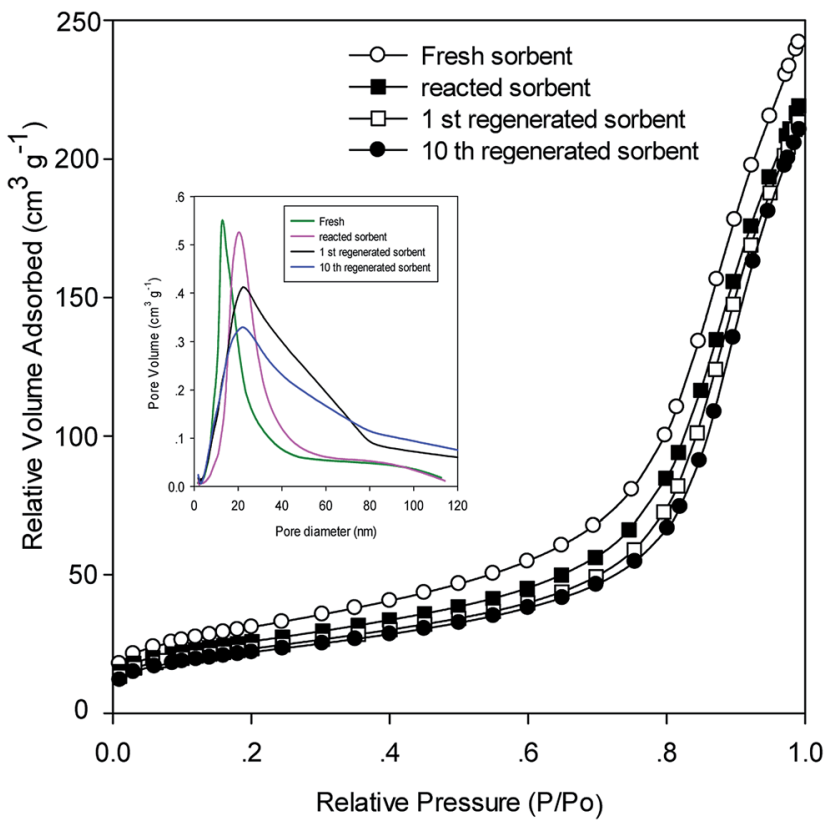

Fig. $7 \mathrm{~N}_{2}$ adsorption isotherm of $10 \mathrm{wt} \% \mathrm{ZnMn}_{2} \mathrm{O}_{4} / \mathrm{SiO}_{2}$ sorbent at different status.

of elemental $\mathrm{Zn}$ at $550{ }^{\circ} \mathrm{C}$. The $\mathrm{Zn}$ and $\mathrm{Mn}$ contents and the recovery (\%) of various samples are listed in Table 1 . As expected, the recoveries of $\mathrm{Zn}$ and $\mathrm{Mn}$ were satisfactory, and no vaporization or loss was observed. The sulfur content was measured by EA. The sulfur content were $1.97 \%, 1.91 \%$, and $1.89 \%$ for $600{ }^{\circ} \mathrm{C}, 700{ }^{\circ} \mathrm{C}$, and $750{ }^{\circ} \mathrm{C}$, respectively which is corresponding to the result of Fig. 2. It is also observed the presence of sulfur after regeneration sorbent. Residual sulfur presence probably came from the incompleted regeneration reaction.

\subsection{XRD patterns}

XRD was used to understand the changes in the crystal phase of the fresh, reacted and regenerated $\mathrm{ZnMn}_{2} \mathrm{O}_{4} / \mathrm{SiO}_{2}$ sorbents after multiple desulfurization/regeneration cycles. The XRD patterns of various states of sorbents were displayed in Fig. 8. As can be seen that the fresh sorbent has an amorphous structure in which a smooth peak located around at $2 \theta=23^{\circ}$ is assigned to the $\mathrm{SiO}_{2}$ support [PDF\#39-1425]. On the other hand, the specific peaks at $2 \theta=29.3^{\circ}, 33^{\circ}, 36.4^{\circ}$, and $60.8^{\circ}$ were attributed to the reflection of $\mathrm{ZnMn}_{2} \mathrm{O}_{4}$ [PFD\#05-0602], implying that all of $\mathrm{Zn}$ and $\mathrm{Mn}$ were completely reacted to form the spinel structure. No other Si-Zn-Mn oxides were detected, indicating that the interaction between $\mathrm{SiO}_{2}$ and $\mathrm{Zn} / \mathrm{Mn}$ can be ignored during calcinations process. After reaction the major peaks were observed at $2 \theta=34.2^{\circ}$ and $49.2^{\circ}$ are ascribed to the diffraction of MnS [PFD\#65-0891], whereas $2 \theta=26.9^{\circ}, 28.5^{\circ}, 30.5^{\circ}$ and $47.5^{\circ}$ are assigned to the reflection of ZnS [PFD\#65-0891]. Note that no $\mathrm{Zn} / \mathrm{Mn}$ oxides were observed after reaction, implying that the spinel structures of $\mathrm{ZnMn}_{2} \mathrm{O}_{4}$ sorbent were completely converted into $\mathrm{ZnS}$ and $\mathrm{MnS}$. After regeneration the sorbent possessed the same diffraction pattern in comparison with 
fresh one. It is noteworthy that the intensity of MnS signals gradually decreased with reaction cycle and was not detected for the reacted sorbent after ten cycles. Previous study prepared Mn-based sorbents for high temperature desulfurization and a series of steam contents were carried out for desulfurization reaction. According to experimental results, the diffraction peaks of MnS weakened with incremental steam content, which showed that the desulfurization reaction was strongly influenced in the atmosphere. ${ }^{29}$ Another possible reasons is ascribed to the well dispersed as an amorphous phase or as nanocrystallites after multiple desulfurization/regeneration cycles., ${ }^{5,30}$ In addition to the MnS disappearance, an obvious reflection signal at $2 \theta=21.9^{\circ}$ was assigned to the diffraction of well-crystalline structure of $\mathrm{SiO}_{2}$ [PFD\#46-1045]. The reaction between metal sulfides and $\mathrm{O}_{2}$ is highly exothermic and accompanying many times of desulfurization/regeneration cycles, an amorphous $\mathrm{SiO}_{2}$ may result in lattice transformation due to the high temperature rise. The well-crystalline structure of $\mathrm{SiO}_{2}$ was firstly observed in the regenerated sorbent after three cycles. Although the well-crystalline structure of $\mathrm{SiO}_{2}$ was formed during regeneration process, there is no change in
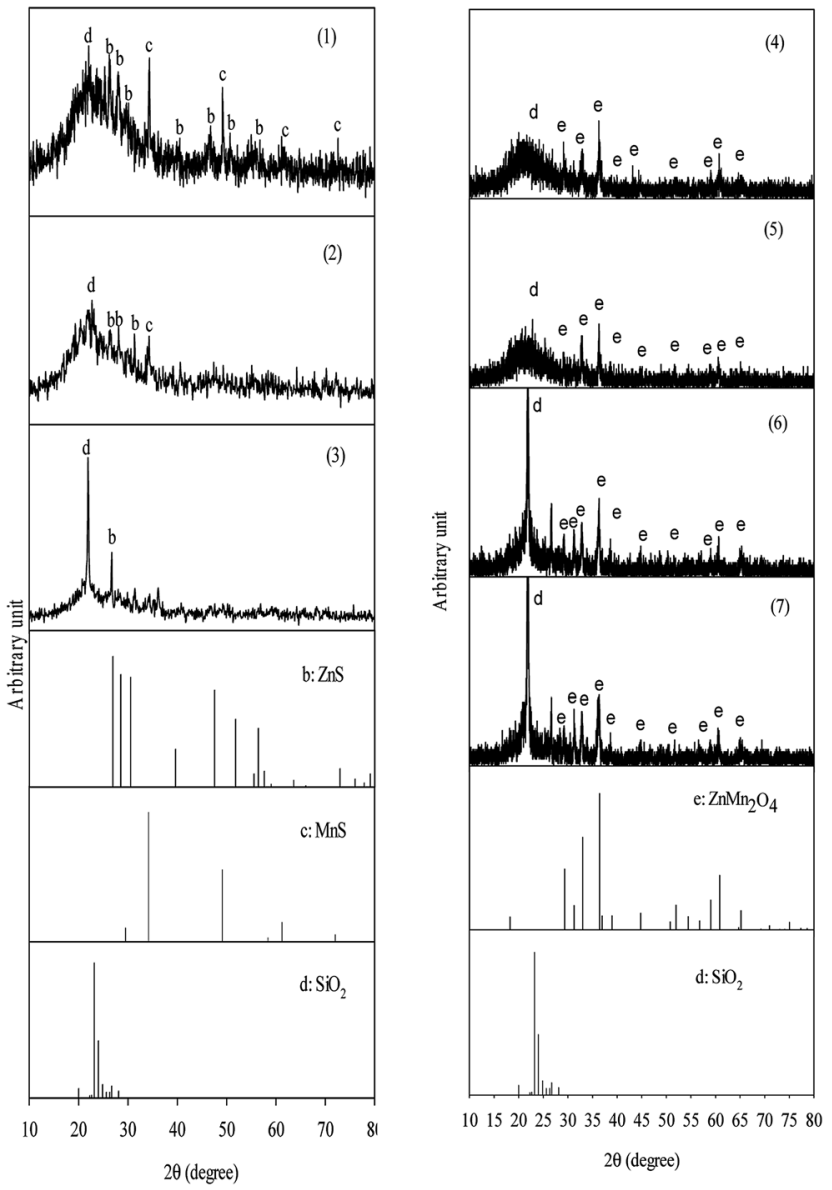

Fig. 8 XRD patterns of the $\mathrm{ZnMn}_{2} \mathrm{O}_{4} / \mathrm{SiO}_{2}$ sorbent in various reactions, (1) reacted sorbent (2) reacted sorbent after three cycles (3) reacted sample after ten cycles (4) fresh sorbent (5) regenerated sorbent (6) regenerated sorbent after three cycles (7) regenerated sorbent after ten cycles. the presence of $\mathrm{ZnMn}_{2} \mathrm{O}_{4}$ even after ten desulfurization/ regeneration cycle. This result is consistence with the analysis of ICP (shown in Table 1), in which the recoveries of $\mathrm{Zn}$ and $\mathrm{Mn}$ maintained at least $99 \%$. Ahmed et al. ${ }^{31}$ verified that spinel oxides were significantly decomposed and the single metal oxide appeared during the continuous desulfurization/ regeneration cycles. From the present results obtained, the formation of $\mathrm{ZnMn}_{2} \mathrm{O}_{4}$ overcame the vaporization of $\mathrm{Zn}$ at high temperature.

\subsection{XAS and SSNMR identification}

The XRD patterns showed the disappearance of MnS and a significant peak of $\mathrm{SiO}_{2}$ were observed after multiple desulfurization/regeneration cycles. For better understand the fine structure of $\mathrm{MnS}$ after multiple desulfurization/ regeneration cycles, the reacted, regenerated sorbents after ten cycles, and reference materials were evaluated by the X-ray synchrotron radiation. The extended X-ray absorption fine structure fitting results revealed that the $\mathrm{Mn}-\mathrm{S}$ bond length was $2.582 \AA$ for the reacted $\mathrm{ZnMn}_{2} \mathrm{O}_{4}$ sorbent. $\mathrm{Mn}-\mathrm{S}$ bond length for the regenerated sorbent after ten cycles was $2.486 \AA$, which is longer than that of the reacted sorbent. In addition, we also evaluated the local atomic structure in $\mathrm{Zn}_{1-x} \mathrm{Mn}_{x} \mathrm{~S}$. We found that the Mn-S bond length were 2.415, 2.418 and $2.421 \AA$ for $\mathrm{Zn}_{0.88} \mathrm{Zn}_{0.12} \mathrm{~S}, \quad \mathrm{Zn}_{0.8} \mathrm{Mn}_{0.2} \mathrm{~S}$ and $\mathrm{Zn}_{0.67} \mathrm{Mn}_{0.33} \mathrm{~S}$, respectively. Based on our finding, it is speculated that the composition of $\mathrm{Mn}-\mathrm{S}$ after ten desulfurization/regeneration cycles is a nonstoichiometric structure with zinc. The possible structure of can be expressed as $\mathrm{Zn}_{1-x} \mathrm{Mn}_{x} \mathrm{~S}$, where $x$ ranged from 0.33 to one and maybe present in amorphous phase. In order to understand the structural changes in $\mathrm{SiO}_{2}$ before and after regeneration in $\mathrm{ZnMn}_{2} \mathrm{O}_{4}$ sorbent, ${ }^{29} \mathrm{Si}$ MAS NMR was measured and fitted by Origin software. Generally, four types of ${ }^{29} \mathrm{Si}$ spectra are identified, namely $\mathrm{Q}^{1}, \mathrm{Q}^{2}, \mathrm{Q}^{3}$ and $\mathrm{Q}^{4}\left(\mathrm{Q}^{n}\right.$ represents the $\mathrm{SiO}_{4}$ tetrahedron of the amorphous network which forms $n$ bonds with neighboring tetrahedral). The analyses and deconvolution results is tabulated in Table 2 . The ${ }^{29} \mathrm{Si}$ spectrum of the fresh $\mathrm{ZnMn}_{2} \mathrm{O}_{4} / \mathrm{SiO}_{2}$ contain a main resonance at around -109.6 ppm corresponding to a trioctahedral structure with four oxygen neighbors and is assigned to the $\mathrm{Q}^{4}$ structure. The pronounced moderate peak located at $-101.6 \mathrm{ppm}$ corresponds to $\mathrm{Q}^{3},(\mathrm{SiO})_{3} \mathrm{Si}(\mathrm{OH})$ is attached to one hydroxyl group and three $\mathrm{Si}-\mathrm{O}-\mathrm{Si}$ bonds. The signal located at $-92.1 \mathrm{ppm}$ is assigned to the $\mathrm{Q}^{2}$ structure, $(\mathrm{SiO})_{2} \mathrm{Si}(\mathrm{OH})_{2}$ is bound to two hydroxyl group and two Si-O-Si bonds. The fraction of $\mathrm{Q}^{2}, \mathrm{Q}^{3}$ and $\mathrm{Q}^{4}$ are $8.3 \%$, $20.4 \%$ and $71.3 \%$, respectively. This implies that the major $\mathrm{Si}$ structure in fresh sample is a bulk siloxane group connected with four Si-O-Si bonds. As shown in Table 2, no $\mathrm{Q}^{2}$ signal was detected and fractions of $\mathrm{Q}^{3}$ decreased for the regenerated and reacted sorbents after triple and ten cycles. The hydroxyl groups presented in $\mathrm{Q}^{2}$ and $\mathrm{Q}^{3}$ gradually disappeared from the crystal lattice of silica oxide because of the extremely heat released from the regeneration reaction at high temperature. The fraction of $\mathrm{Q}^{3}$ significantly decreased and a fraction of $\mathrm{Q}^{4}$ increased for regenerated and reacted sorbent after multiple cycles. In fact, the regeneration reaction is a highly exothermic reaction 
and it is believed that the highly exothermic reaction leads to the change in ${ }^{29} \mathrm{Si}$ chemical shift. On the basis of XAS and SSMNR, it is summarily concluded that the disappearance of $\mathrm{MnS}$ in XRD is probably attributed to the nonstoichiometric structure of $\mathrm{Zn}_{1-x} \mathrm{Mn}_{x} \mathrm{~S}$. On the other hand, the well-crystalline of $\mathrm{SiO}_{2}$ results from the transformation of spatial structure in lattice.

\subsection{TPR analysis}

Fig. 9 shows the TPR patterns of the reacted sorbent with a series of $\mathrm{MnS}, \mathrm{ZnS}, \mathrm{ZnSO}_{4}$, and $\mathrm{MnSO}_{4}$ standard samples. For MnS standard sample, two evident peaks were detected and the first peak located at $400{ }^{\circ} \mathrm{C}$ is assigned to the oxidation of $\mathrm{MnS}$ to $\mathrm{Mn}_{3} \mathrm{O}_{4}$. The second one located at $800{ }^{\circ} \mathrm{C}$ is due to the formation of $\mathrm{MnSO}_{4}$, which comes from the reaction of $\mathrm{MnO}_{x}$ and $\mathrm{SO}_{2}$. For $\mathrm{ZnS}$ standard sample, two obvious peaks were measured at higher temperature, namely at $625{ }^{\circ} \mathrm{C}$ and $850{ }^{\circ} \mathrm{C}$, respectively. They are assigned to the reactions of the oxidation of $\mathrm{ZnS}$ to $\mathrm{ZnO}$, and the formation of $\mathrm{ZnSO}_{4}$, respectively. It is remarkable that the formation of metal sulfates during regeneration process. Metal sulfates were undesired by-products, which were inevitably formed due to thermodynamic favorable property with $\mathrm{O}_{2}$ and may inhibit the diffusion of $\mathrm{O}_{2}$, thereby restraining the regeneration of the interior region of the sorbent. ${ }^{32}$ Unlike metal sulfides, only one peak was obviously detected for both $\mathrm{MnSO}_{4}$ and $\mathrm{ZnSO}_{4}$ standard samples. The peak for $\mathrm{MnSO}_{4}$ and $\mathrm{ZnSO}_{4}$ standard sample is located at $775{ }^{\circ} \mathrm{C}$ and $825{ }^{\circ} \mathrm{C}$, respectively. Therefore, it can be concluded that the $\mathrm{MnSO}_{4}$ and $\mathrm{ZnSO}_{4}$ may be decomposed at the temperature higher than of $775{ }^{\circ} \mathrm{C}$ and $825^{\circ} \mathrm{C}$. For the reacted sorbent, three major peaks appeared at $400{ }^{\circ} \mathrm{C}, 625{ }^{\circ} \mathrm{C}$, and $825{ }^{\circ} \mathrm{C}$ were detected. This illustrated that the regeneration of the reacted sorbent had three stages. The signal at $400{ }^{\circ} \mathrm{C}$ was assigned to the conversion of $\mathrm{MnS}$ into $\mathrm{Mn}_{3} \mathrm{O}_{4}$ whereas the peak at $625^{\circ} \mathrm{C}$ was assigned to the conversion of $\mathrm{ZnS}$ into ZnO. Note that a small peak appeared at $550{ }^{\circ} \mathrm{C}$ was found. The most likely explanation is that the decomposition and oxidation of $\mathrm{ZnS}$ that coated on the surface of reacted sorbent. Similar to the second peak, a shoulder peak was also observed at $775{ }^{\circ} \mathrm{C}$ and was attributed to the decomposition of $\mathrm{MnSO}_{4}$. There is no doubt that the final peak appeared at $825{ }^{\circ} \mathrm{C}$ was assigned to the decomposition of $\mathrm{ZnSO}_{4}$. The regeneration temperature in this study was controlled at $650{ }^{\circ} \mathrm{C}$, which is relatively lower than the

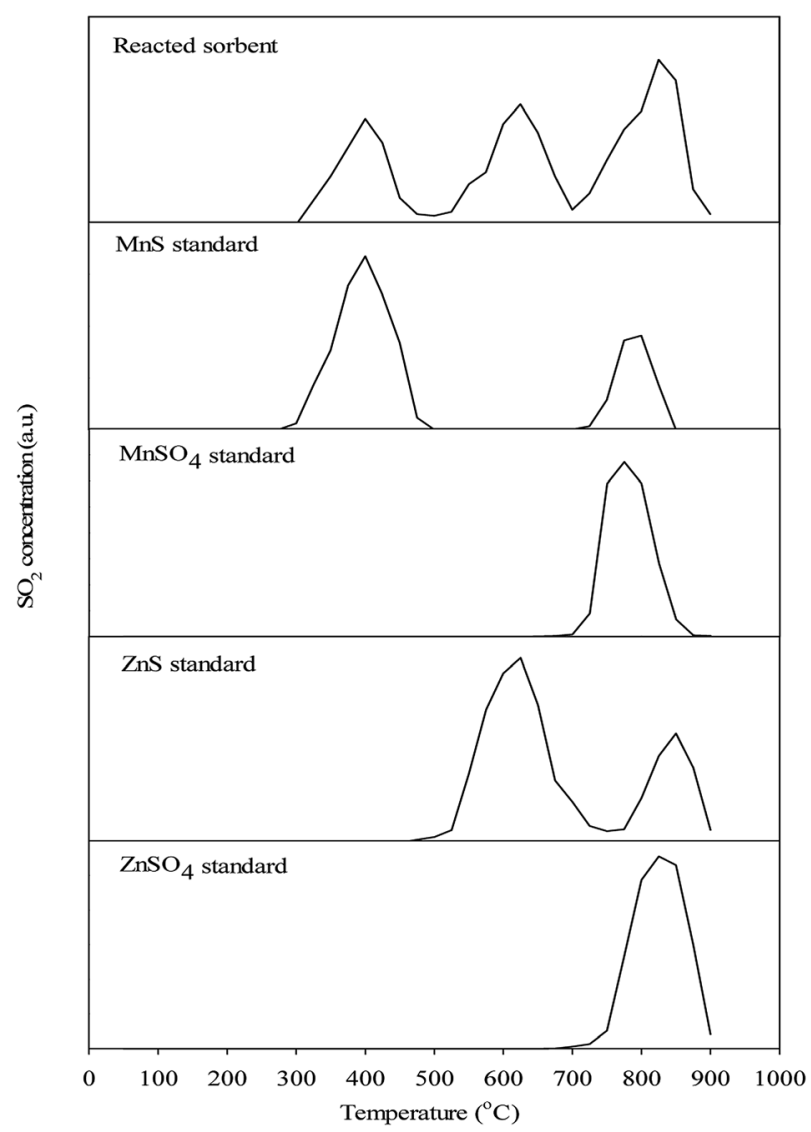

Fig. 9 Temperature programmed regeneration (TPR) patterns of the reacted $\mathrm{ZnMn}_{2} \mathrm{O}_{4} / \mathrm{SiO}_{2}$ sorbent and reference compounds.

requirement of TPR result. In fact, the regeneration is a highly exothermic reaction and actual temperature should be higher than the regeneration temperature. To confirm this viewpoint, the internal temperature of reacted sorbent during regeneration process was experimentally monitored. As expected, although regeneration temperature was controlled at $650{ }^{\circ} \mathrm{C}$, the internal temperature was measured about $780{ }^{\circ} \mathrm{C}$. Unfortunately, the internal temperature of $780{ }^{\circ} \mathrm{C}$ appeared too low to complete the regeneration reaction according to the TPR observation and resulted in the presence of metal sulfates due to incomplete reaction.

Table $2{ }^{29} \mathrm{Si}$ MAS NMR fitting results and deconvolution of $Q^{n}$ species for different status of $\mathrm{ZnMn}_{2} \mathrm{O}_{4} / \mathrm{SiO}_{2}{ }^{a}$

\begin{tabular}{|c|c|c|c|c|c|c|c|c|c|}
\hline \multirow[b]{2}{*}{ Sample status } & \multicolumn{3}{|l|}{$\mathrm{Q}^{2}$} & \multicolumn{3}{|l|}{$\mathrm{Q}^{3}$} & \multicolumn{3}{|l|}{$\mathrm{Q}^{4}$} \\
\hline & FWHM (ppm) & $\begin{array}{l}\delta \\
(\mathrm{ppm})\end{array}$ & $I(\%)$ & FWHM (ppm) & $\begin{array}{l}\delta \\
(\mathrm{ppm})\end{array}$ & $I(\%)$ & FWHM (ppm) & $\begin{array}{l}\delta \\
(\mathrm{ppm})\end{array}$ & $I(\%)$ \\
\hline Fresh sorbent & 8.2 & -92.1 & 8.3 & 6.4 & -101.6 & 20.4 & 5.7 & -109.6 & 71.3 \\
\hline Reacted sorbent & 9.1 & -94.2 & 5.1 & 7.0 & -101.8 & 17.5 & 6.3 & -110.3 & 77.4 \\
\hline Regenerated sorbent (triple cycles) & - & - & - & 7.4 & -105.2 & 8.4 & 6.8 & -111.5 & 92.6 \\
\hline Regenerated sorbent (ten cycles) & - & - & - & 7.8 & -106.4 & 4.8 & 6.9 & -112.7 & 96.2 \\
\hline Reacted sorbent (ten cycles) & - & - & - & 7.8 & -106.3 & 5.1 & 6.6 & -112.8 & 94.9 \\
\hline
\end{tabular}

${ }^{a} \mathrm{FWHM}, \delta$ and $I$ represent the full width at half maximum, ${ }^{29} \mathrm{Si}$ chemical shift, and relative intensity, respectively. Error value: FWHM \pm 0.4 ppm, $\delta \pm 1.5 \mathrm{ppm}, I \pm 3.6 \%$. 


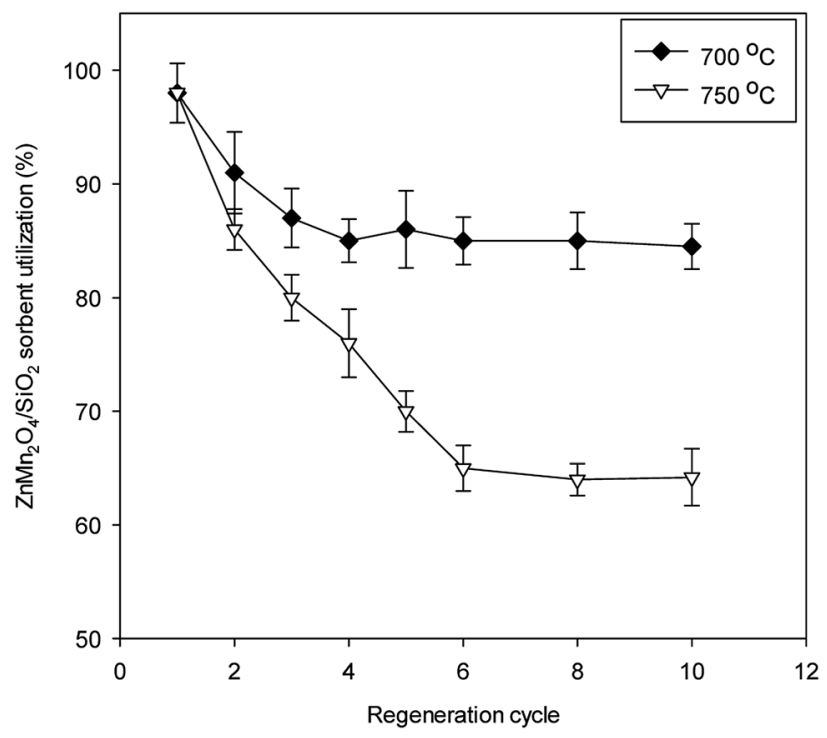

Fig. $10 \mathrm{ZnMn} 2 \mathrm{O}_{4} / \mathrm{SiO}_{2}$ sorbent utilization as a function of multiple desulfurization/regeneration cycles at $700{ }^{\circ} \mathrm{C}$ and $750{ }^{\circ} \mathrm{C}$.

The TPR result showed that the temperature to complete regeneration reaction for $\mathrm{ZnMn}_{2} \mathrm{O}_{4} / \mathrm{SiO}_{2}$ sorbent should be set at $825{ }^{\circ} \mathrm{C}$. Therefore, two sets of different regeneration temperature were conducted based on the identical condition at the regeneration temperature of $650{ }^{\circ} \mathrm{C}$. Experimental results show that the regeneration temperature of $700^{\circ} \mathrm{C}$ appears to have the better sorbent utilization than that of $750{ }^{\circ} \mathrm{C}$ (Fig. 10). After sixth desulfurization/regeneration cycles, the sorbent utilization maintain stable state. The stable sorbent utilization for $650{ }^{\circ} \mathrm{C}$, $700{ }^{\circ} \mathrm{C}$, and $750{ }^{\circ} \mathrm{C}$ are approximately at $70 \%, 85 \%$, and $65 \%$, respectively. In addition, the internal temperatures during regeneration process were $843{ }^{\circ} \mathrm{C}$ and $876{ }^{\circ} \mathrm{C}$ for the regeneration temperature of $700{ }^{\circ} \mathrm{C}$ and $750{ }^{\circ} \mathrm{C}$. Note that the higher regeneration temperature $\left(750{ }^{\circ} \mathrm{C}\right)$ cannot achieve the better sorbent utilization after multiple cycles. The internal temperature of $876{ }^{\circ} \mathrm{C}$ likely leads to the sintering phenomenon and further results in sorbent degradation due to the loss of surface area. ICP measurements demonstrated that the Zn recovery was 98.5\%, which confirms no $\mathrm{Zn}$ vaporization during desulfurization/ regeneration cycles at the regeneration temperature of $750{ }^{\circ} \mathrm{C}$. However, the surface area decreased by $32 \mathrm{~m}^{2} \mathrm{~g}^{-1}$ and small pore structures was distinctly destructed. It is believed that the temperature of $700^{\circ} \mathrm{C}$ is the optimal operating choice because of higher sorbent utilization after multiple cycles.

The SEM and EDS images of different sorbents status are shown Fig. 11. The surface of the fresh sorbent was loose and porous. After desulfurization, compact and dense particles were observed on the surface of the reacted sorbent. The sulfur content in the reacted sorbent was estimated about $13.3 \%$, indicating that the $\mathrm{H}_{2} \mathrm{~S}$ were reacted with $\mathrm{ZnMn}_{2} \mathrm{O}_{4} / \mathrm{SiO}_{2}$ to form metal sulfides ( $\mathrm{MnS}$ and $\mathrm{ZnS}$ ). For the regenerated sorbent (after three desulfurization/regeneration cycles) the porous structure was partially restored, which reflected the slight decrease in BET surface. Compared with the fresh sorbent, it is clear observed that the well-crystalline structure appeared after regeneration.

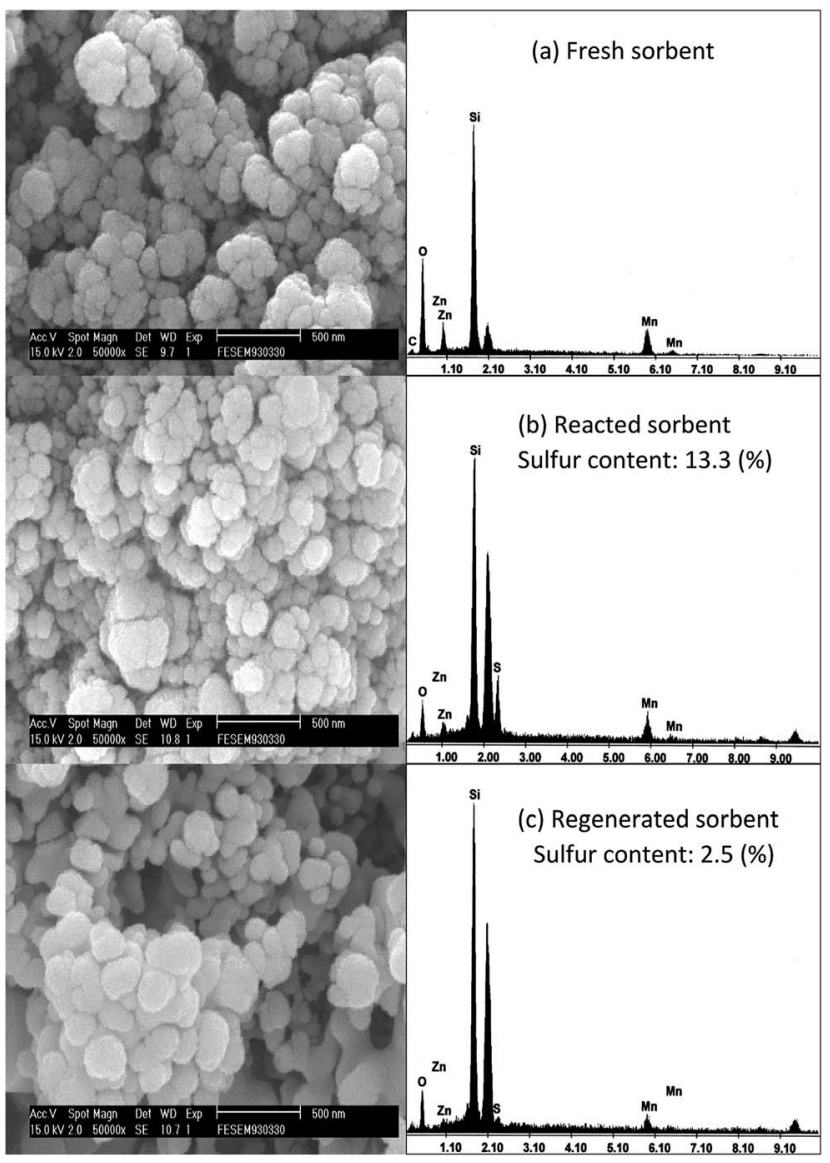

Fig. 11 SEM images and EDS patterns of the (a) fresh (b) reacted (c) regenerated $\mathrm{ZnMn}_{2} \mathrm{O}_{4} / \mathrm{SiO}_{2}$ sorbent.

Furthermore, it can be found that the presence of sulfur in the regenerated sorbent and it may be attributed to the formation of metal sulfates due to incomplete regeneration reaction. According to the results of TPR the one of reasons for the loss of activity of $\mathrm{ZnMn}_{2} \mathrm{O}_{4}$ is the formation of metal sulfate, and an increase in the regeneration temperature is believed to overcome the problem of the formation of metal sulfate.

\section{Conclusions}

A spinel structure of the $\mathrm{ZnMn}_{2} \mathrm{O}_{4}$ sorbent supported on $\mathrm{SiO}_{2}$ was fabricated for high temperature desulfurization. Multiple desulfurization/regeneration cycles were conducted to assess the ability of the $\mathrm{ZnMn}_{2} \mathrm{O}_{4} / \mathrm{SiO}_{2}$ sorbent. The $\mathrm{ZnMn}_{2} \mathrm{O}_{4} / \mathrm{SiO}_{2}$ sorbent utilization was retained at $70 \%$ and no $\mathrm{Zn}$ vaporization was observed after ten desulfurization/regeneration cycles. According to the XRD results, no major changes in the crystal phases occurred after multiple cycles. Through the EA, EDS and TPR analyses, the residual sulfur was found in the regenerated sorbent and this sulfur species is sulphate which resulted by incompleted regeneration. It is suggested that the regeneration temperature of $700{ }^{\circ} \mathrm{C}$ should be the best condition and maintains the sorbent utilization at $85 \%$ after multiple cycles. 


\section{Acknowledgements}

This work was partially funded by Anxi College of Tea Science, Fujian Agriculture and Forestry University and Yung-Hsing Financial Workshop Cooperation Company.

\section{Notes and references}

1 S. Cheah, D. L. Carpenter and K. A. Magrini-Bair, Energy Fuels, 2009, 23, 5291-5307.

2 N. R. Jeon, H. S. Song, M. G. Park, S. J. Kwon, H. J. Ryu and K. B. Yi, Clean technology, 2013, 19, 300-305.

3 B. Guo, L. Chang and K. Xie, Ind. Eng. Chem. Res., 2014, 53, 8874-8880.

4 K. Svoboda, J. Leitner, J. Havlica, M. Hartman, M. Pohorely, J. Brynda, M. Syc, Y. P. Chyou and P. C. Chen, Fuel, 2017, 197, 277-289.

5 H. Xia and B. Liu, J. Hazard. Mater., 2017, 324, 281-290.

6 K. Y. Chang and E. S. Jae, Adv. Powder Technol., 2010, 21, 119124.

7 J. B. Gibson and D. P. Harrison, Ind. Eng. Chem. Process Des. Dev., 1980, 19, 231-237.

8 M. Mureddu, I. Ferino, E. Rombi, M. G. Cutrufello, P. Deiana, A. Ardu, A. Musinu, G. Piccaluga and C. Cannas, Fuel, 2012, 102, 691-700.

9 V. Girard, D. Chiche, A. Baudot, D. Bazer-Bachi, I. Clemencon, F. Moreau and C. Geantet, Fuel, 2015, 140, 453-461.

10 R. E. Ayala and D. W. Marsh, Ind. Eng. Chem. Res., 1991, 30, 55-60.

11 T. H. Ko, Environ. Chem. Lett., 2011, 9, 77-82.

12 J. P. Wakker, A. W. Gerritsen and J. A. Moulijn, Ind. Eng. Chem. Res., 1993, 32, 139-149.

13 L. Alonso, J. M. Palacios, E. Garcia and R. Moliner, Fuel Process. Technol., 2000, 62, 31-44.

14 S. Cheah, J. L. Olstad, W. S. Jablonski and M. Bair, Energy Fuels, 2011, 25, 379-387.
15 Z. B. Huang, B. S. Liu, F. Wang and R. Amin, Appl. Surf. Sci., 2015, 353, 1-10.

16 L. F. Guo, K. L. Pan, H. M. Lee and M. B. Chang, Ind. Eng. Chem. Res., 2015, 54, 11040-11047.

17 T. H. Ko, H. Chu and Y. J. Liu, J. Hazard. Mater., 2007, 147, 334-341.

18 S. Lew, A. F. Sarofim and M. Flytzani-Stephanopoulos, Ind. Eng. Chem. Res., 1992, 31, 1890-1899.

19 J. C. Zhang, Y. H. Wang, R. Y. Ma and D. Y. Wu, Fuel Process. Technol., 2003, 84, 217-227.

20 J. C. Wang, B. Qiu, L. Han, G. Feng, Y. F. Hu, L. P. Chang and W. R. Bao, J. Hazard. Mater., 2012, 213-214, 184-192.

21 B. S. Liu, X. N. Wei, Y. P. Zhan, R. Z. Chang, F. Subhan and C. T. Au, Appl. Catal., B, 2011, 102, 27-36.

22 J. Zhang, Y. Wang and D. Wu, Energy Convers. Manage., 2003, 44, 357-367.

23 J. Wang, B. Liang and R. Parnas, Fuel, 2013, 107, 539-546.

24 R. S. Sonawance, S. G. Hegde and M. K. Dongare, Mater. Chem. Phys., 2000, 77, 744-750.

25 C. S. Fang and Y. W. Chen, Mater. Chem. Phys., 2003, 78, 739745.

26 W. F. Elseviers and H. Verelst, Fuel, 1999, 78, 601-612.

27 R. B. Slimane and J. Abbasian, Adv. Environ. Res., 2000, 4, 147-162.

28 L. D. Galvin, A. T. Atimtay and R. P. Gupta, Ind. Eng. Chem. Res., 1998, 37, 4157-4166.

29 Z. B. Huang, B. S. Liu, X. Y. Tang, X. H. Wang and R. Amin, Fuel, 2016, 177, 217-225.

30 K. Polychronopoulou, J. L. G. Fierro and A. M. Efstathiou, Appl. Catal., B, 2005, 57, 125-137.

31 M. A. Ahmed, L. Alonso, J. M. Palacios, C. Cilleruelo and J. C. Abanades, Solid State Ionics, 2000, 138, 51-62.

32 J. Wang, J. Guo, R. Parnas and B. Liang, Fuel, 2015, 154, 1723. 